\title{
Article
}

\section{Woody Guthrie, American Radical}

\author{
Kaufman, William \\ Available at https://clok.uclan.ac.uk/7419/ \\ Kaufman, William orcid iconORCID: 0000-0002-5206-647X (2013) Woody \\ Guthrie, American Radical. American Studies in the UK Impact and Public \\ Engagement . p. 6.
}

It is advisable to refer to the publisher's version if you intend to cite from the work.

For more information about UCLan's research in this area go to

http://www.uclan.ac.uk/researchgroups/ and search for < name of research Group>.

For information about Research generally at UCLan please go to http://www.uclan.ac.uk/research/

All outputs in CLoK are protected by Intellectual Property Rights law, including Copyright law. Copyright, IPR and Moral Rights for the works on this site are retained by the individual authors and/or other copyright owners. Terms and conditions for use of this material are defined in the policies page.

\section{CLoK}

Central Lancashire online Knowledge www.clok.uclan.ac.uk

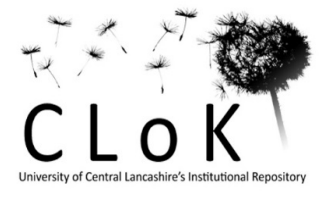




\section{American Studies in the UK}

The impact of American Studies research in the United Kingdom years and has enhanced the public understanding of the history, culture and politics of the United States.

\section{American Studies research in the} UK spans a group of subjects drawn from the arts, humanities and social sciences: United States history; American and comparative literature; US politics (including government, foreign policy and international relations); and North American culture (including film, television, theatre, visual art, music and the mass media). The interdisciplinary has been immense over the last 60 nature of American Studies is at the core of the diverse range of projects profiled in this brochure.

The case studies collected here are all ambitious projects that push beyond disciplinary boundaries and take academic research directly into the public sphere. All these projects many of which are collaborative and international in scope - have attracted external funding for the ways in which they challenge our preconceptions and deepen our understanding about the past, present and future of the United States from regional, national, transatlantic and global perspectives.

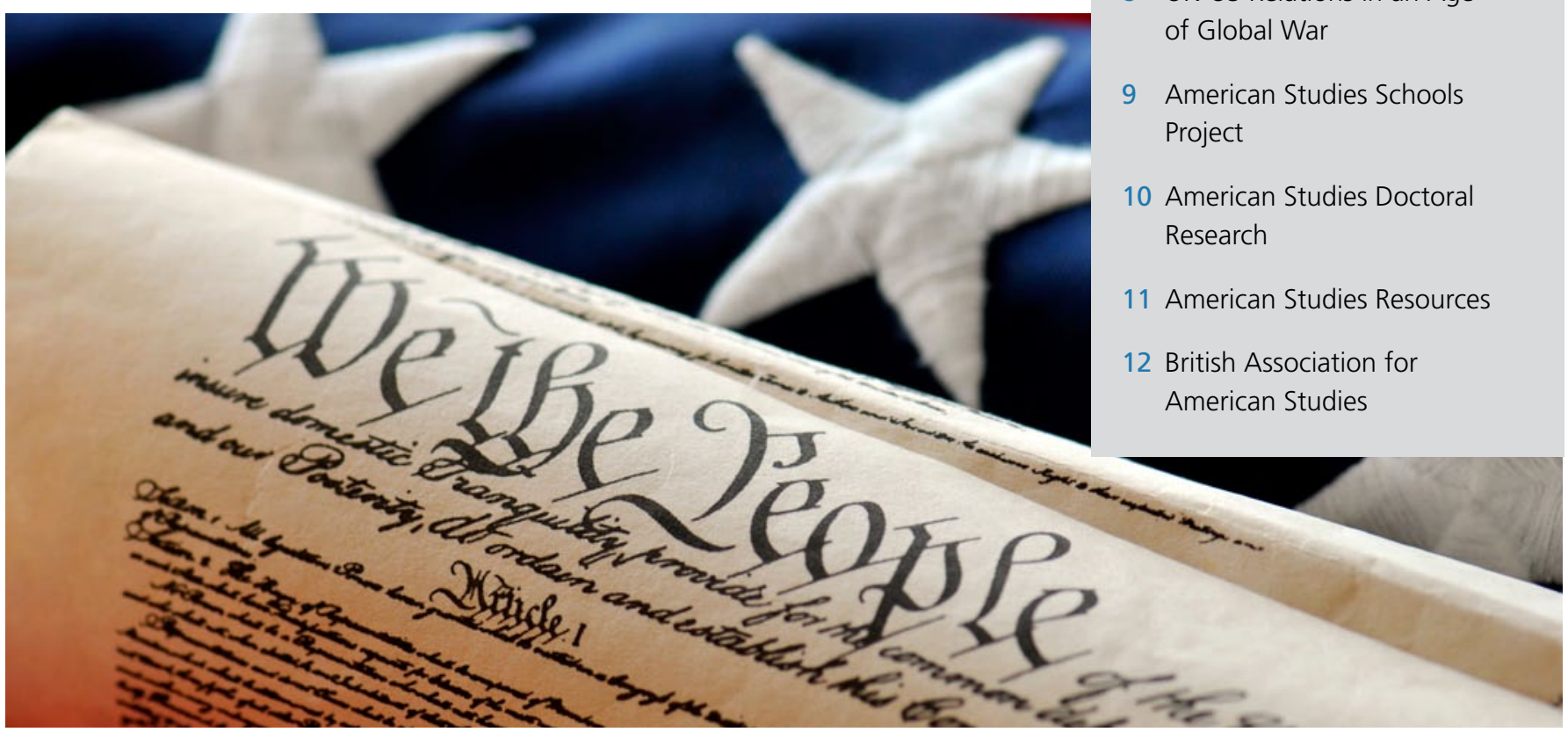

\section{Contents}

1 Cultures of the Suburbs

2 North American Print Cultures

3 Woody Guthrie, American Radical

4 Translating Penal Cultures

5 Un-Americans and the Un-American

6 The Presidency and Tribal Diplomacy

7 The English in North America

UK-US Relations in an Age of Global War

American Studies Schools Project

American Studies Doctoral Research American Studies

2 I British Association for American Studies I Impact and Public Engagement I www.baas.ac.uk 


\section{Cultures of the Suburbs}

\section{The Cultures of the Suburbs}

international research network brings together researchers from five countries, four continents, and a range of disciplines. The partners in the network - including specialists in literature, sociology, geography, and urban studies - share an interest in the history, growth and future of the suburbs, with a particular emphasis on the ways in which experiences and perceptions of suburbia are shaped by and reflected in cultural practice. Those involved work together with other interested parties - planners, developers, economists, environmental scientists, civic and heritage groups - in order to further the scholarly, professional, and public understanding of the cultures of the modern global suburbs through collaborative international and interdisciplinary research, and thereby address the implications of suburban development.

The project is funded by a three-year Leverhulme Trust grant (2011-14) and is based at the University of Exeter, with links to Kingston University, UK, Hofstra University, USA, Griffiths University, Australia, the National University of Ireland, Maynooth and the University of Witwatersrand, South Africa. The project's primary aim is to understand the role played by different forms of culture in shaping suburban experience and in transmitting the ideals and realities of suburban

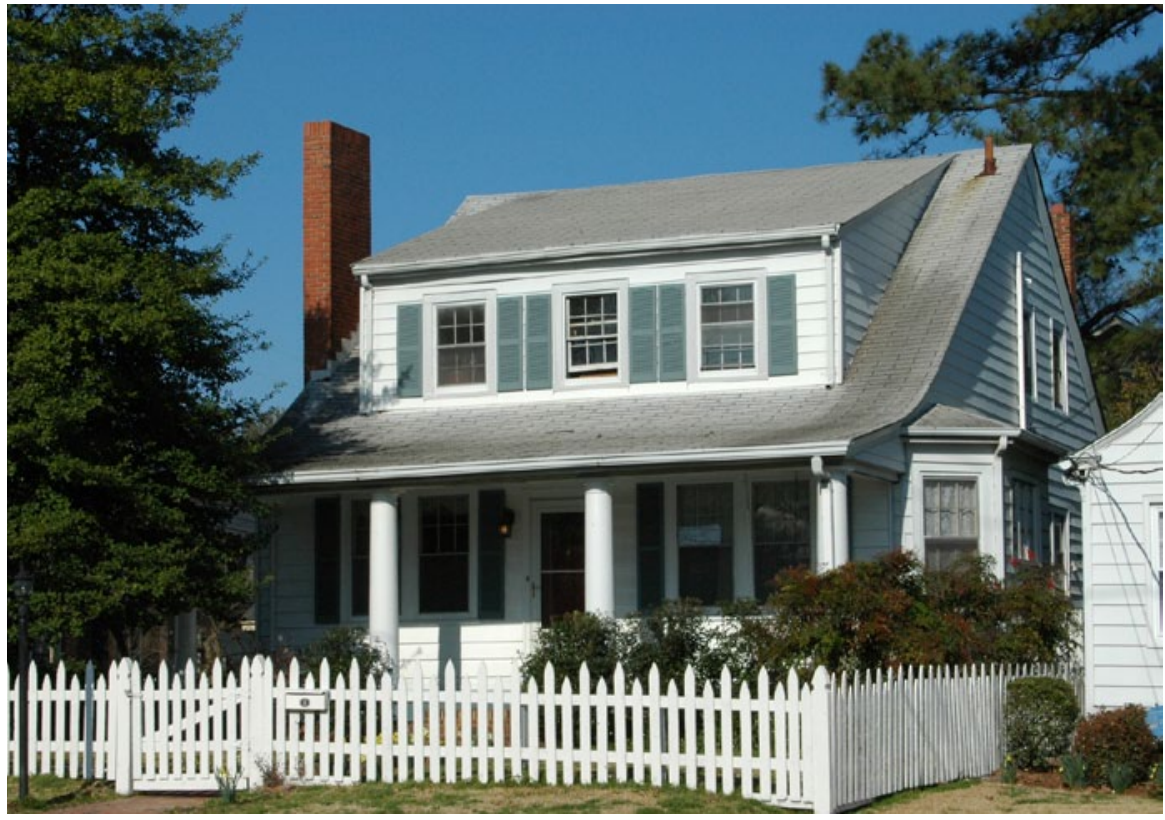

identity. Partners in the network are liaising with architects, planners, and local authorities to understand and inform debates about the suburban environment and working with local schools, community groups and individual residents to explore how specific sectors experience suburbia and create their own cultures and cultural memories.

The project has a publically accessible website that features scholarly work in progress, exhibitions of suburban art and photography, latest news, and other resources. The network hosted an international symposium in Ireland in 2011 and in Hofstra, Long Island in
June 2013, which will be followed by a conference at Exeter in June 2014. By the end of the project the team aims to have established a Journal of Suburban Studies and to have founded an International Suburban Studies Association.

\section{Contact}

Dr Jo Gill
University of Exeter
e: j.r.gill@ex.ac.uk
Dr Jill Sullivan
e: suburbs@ex.ac.uk
w: suburbs.exeter.ac.uk




\section{North American Print Cultures}

This section showcases three projects that demonstrate the breadth of the current interest among American Studies and Canadian Studies researchers in North American print cultures.

\section{Middlebrow}

The Middlebrow:

A Transatlantic Interdisciplinary Research Network, funded by the Arts and Humanities Research Council (2008-10) engages over one hundred researchers in ten countries drawn from the disciplines

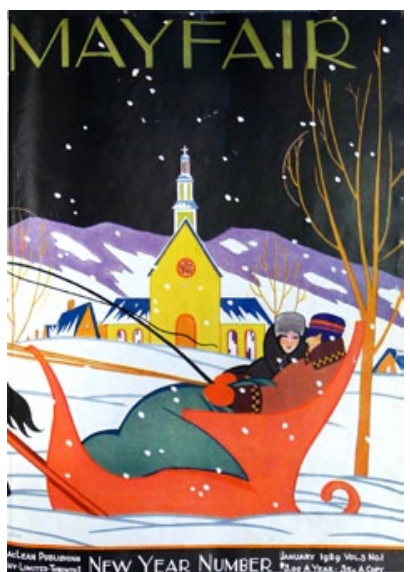

The impact of the project derives from conferences at Sheffeld Hallam and Strathclyde Universities (2008-9), book and journal publications, and a project website. The publically accessible Readerships and Literary Cultures 1900-1950 special collection at Sheffield Hallam University has been augmented by a follow-on project which actively engages community readers with the special collection. This has led of social and cultural history, literature, film and the media to explore and debate the contested and provocative term 'Middlebrow'. In the early-to-mid 20th century, middlebrow referred to the art and culture which lay between high and popular culture, and to tastes and lifestyle choices associated with the middle class. It also referred to aspiration and self-improvement, and to institutions such as book clubs and adult education programmes. The tensions surrounding middlebrow are related to discourses of class and taste which are embodied in a range of lifestyle choices and cultural consumption: from interiors, gardens, design and fashion to preferences in music, film and books. to enhanced library catalogue records with notes on each novel, and has been accompanied by a series of public events and book club meetings. These outputs have stimulated new transatlantic explorations of middlebrow culture from the perspectives of class, gender and nation. A further AHRC-funded project, Magazines, Travel and Middlebrow Culture in Canada 1925-1960 (201113), led by Faye Hammill (Strathclyde), was one of several collaborative projects emerging directly from the network.

\section{Contact}

Professor Faye Hammill

University of Strathclyde

e: faye.hammill@strath.ac.uk

w: www.middlebrow-network.com

\section{Beyond the Book}

Beyond the Book is an interdisciplinary collaborative investigation into the organization, production and reception of large-scale shared reading events or mass reading events - such as radio (Canada Reads), television (Richard and Judy's Book Club), local news media, the internet and face-to-face activities such as the One Book, One Community model. These events aim to involve as many people as possible in reading, discussing or participating in events associated with a selected book. The involvement of government agencies, arts organizations, public institutions (such as libraries and schools), commercial sponsors and broadcast media in

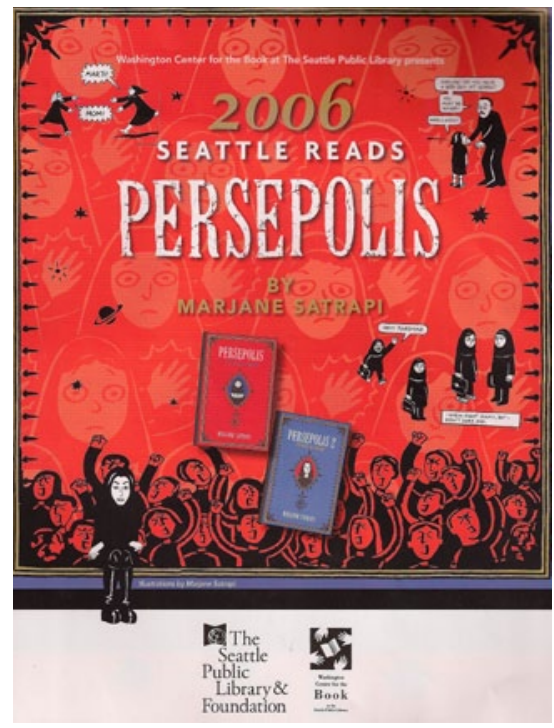


the production of these events raises questions about the social and cultural value attached to print texts and reading in a digital age.

Led by Danielle Fuller at the University of Birmingham and DeNel Rehberg Sedo at Mount Saint Vincent University, Canada - and supported by the AHRC, the British Academy and a Canadian Government grant - the project investigated whether these models of shared reading can enable social change. Focusing on ten locations in the US, Canada and the UK, research methods included interviews with organisers, focus groups with readers, participant observation of activities, analysing event ephemera and media reports, and using an online questionnaire.

Since the main project finished in 2008, the research has contributed to the professional development of public librarians through a series of invited presentations, and the methodologies derived from the project have been the focus of workshops with PhD students and early career scholars in the UK, Finland, Estonia, Australia and Canada.

\section{Contact}

Dr Danielle Fuller

University of Birmingham

e: d.fuller@bham.ac.uk

w: www.beyondthebookproject.org

\section{History of the New Masses Magazine}

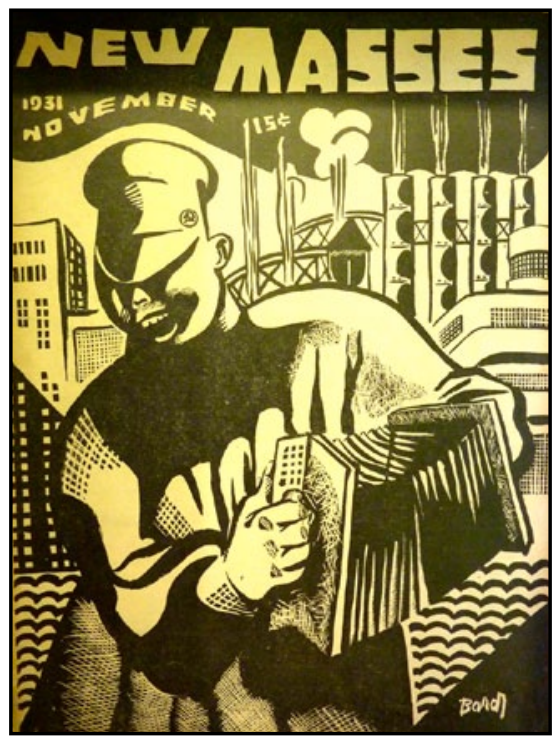

This project, conducted by Sue Currell at the University of Sussex and sponsored by a Leverhulme Research Fellowship (201112), analyses the significance and reach of the American radical arts periodical New Masses, published in the United States between 1926 and 1948. New Masses contained work by some of the most celebrated artists, illustrators and writers of the era, first as a monthly and then a weekly magazine. Aimed at a mass and mixed-class audience and engaging with high and popular arts (ballet, opera, jazz and cinema), New Masses editors saw themselves making a crucial intervention between high and low art in order to communicate left-wing politics and aesthetics to a mass audience.
This project traces the intellectual and artistic development of the magazine using archival materials such as writers' and editors' correspondence, alongside critical analysis of the artistic, written and marketing content of New Masses in order to reassess the role that women, African Americans and Communist Party members played in developing the magazine. The project uniquely looks beyond the printed pages of the magazine to show that New Masses operated as a cultural hub for a huge range of political and social events and performances, such as dances, ballets, lectures, plays, concerts and art auctions.

New Masses had a global reach and engagement with mass culture that was unique compared with other arts and culture magazines of the period. As the most detailed study of the magazine to date, this project makes a significant contribution to the historiography of American cultural modernism and print culture, offering new insights into the artistic and political history of the volatile era spanning the 1920s, the Great Depression, World War II, and into the Cold War.

\section{Contact}
Dr Sue Currell University of Sussex
e: S.Currell@sussex.ac.uk 


\section{Woody Guthrie, American Radical}

In 2008 Will Kaufman (University of Central Lancashire) was awarded a Woody Guthrie Fellowship from the Broadcast Music Industry Foundation and the Woody Guthrie Foundation, to travel to New York to research in the archives devoted to the legendary balladeer and musician, Woody Guthrie (1912-67). An Arts and Humanities Research Council Fellowship also funded his research at the Library of Congress and the Smithsonian Institute in Washington, DC, and a number of private collections, to produce the first political biography of Guthrie, published as Woody Guthrie, American Radical (University of Illinois Press, 2011) to coincide with Guthrie's centenary year, 2012.

But there is another side to Kaufman's scholarship that demonstrates the impact of research into popular American music. He is also a folksinger and multi-instrumentalist, and has been disseminating his research on both sides of the Atlantic with a series of performance programmes - or live documentaries - on the life and times of Woody Guthrie. With song, historical narrative and the projection of powerful images from the Dust Bowl, the Depression and afterwards, this has brought Guthrie's story to audiences at the Glastonbury Festival, the Bath Music Festival, the Tolpuddle Martyrs' Festival in Dorset and countless folk clubs, civic theatres, union halls and universities

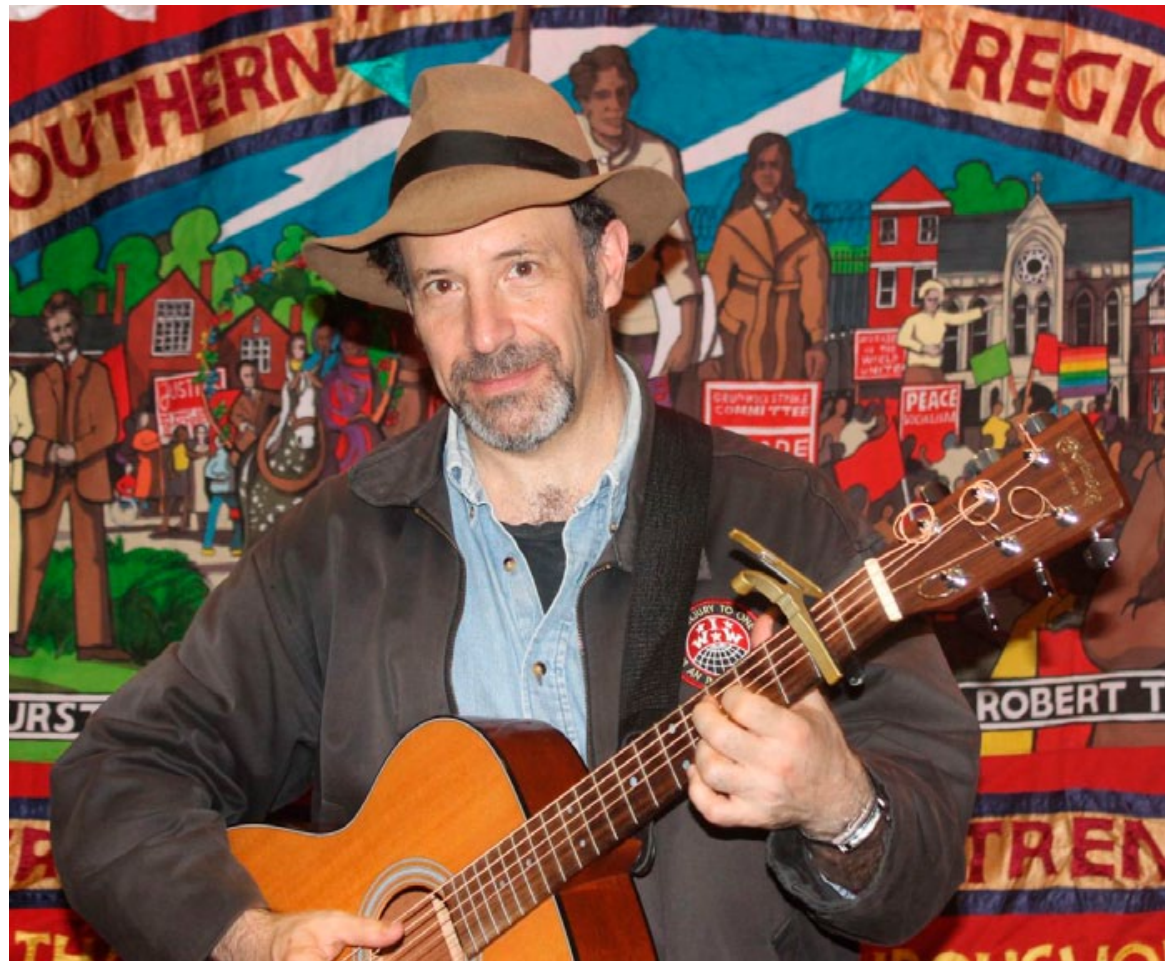

throughout Britain and Europe. He has also performed his shows on a coastto-coast American tour which included broadcasts on National Public Radio, Democracy Now! and C-Span's Book-TV programme.

Will Kaufman has toured extensively with two shows: Woody Guthrie: Hard Times and Hard Travellin' and 'All You Jim Crow Fascists!' Woody Guthrie's Freedom Songs. The first show sets Guthrie's songs in the context of the 1930s: the Dust Bowl, the Depression, the New Deal and the state of popular music itself. The second show reveals a lesser-known side: Guthrie's anti-racist songs and activism. Guthrie left an extensive body of songs condemning Jim Crow segregation, race hatred and fascism, and charting his own personal transformation into a committed civil rights activist.

\section{Contact}

Professor Will Kaufman

University of Central Lancashire

e:WKaufman@uclan.ac.uk w: www.willkaufman.com 


\section{Translating Penal Cultures}

\section{Translating Penal Cultures is an}

interdisciplinary research network of UK-based and international scholars from languages, law, criminology, history, American Studies, cultural studies and political science. Funded by the Arts and Humanities Research Council's Translating Cultures scheme in 2012, the network has currently over 40 members who work on institutions of confinement, practices of crime control, and penal cultures in a range of countries including China (Hong Kong), Russia, Brazil, Mexico, India, the United States, the United Kingdom and Australia. The project grew out of collaborative relationships between researchers in American \& Canadian Studies, History, and Law at the University of Nottingham, University of Leicester, Nottingham Trent University, and Open University.

Following a meeting of UK-based scholars in March 2012, which included a presentation of the documentary Vendemos Recuerdos (Memories for Sale) by Carolina Corral, an anthropologist doctoral student and filmmaker at the University of Manchester, an international symposium with researchers from the UK, Hong Kong, Mexico, Austria, and Germany took place at the University of Nottingham in July 2012. The AHRC funding facilitated participation by three international speakers: Lawrence Ho, a political scientist from Lingnan

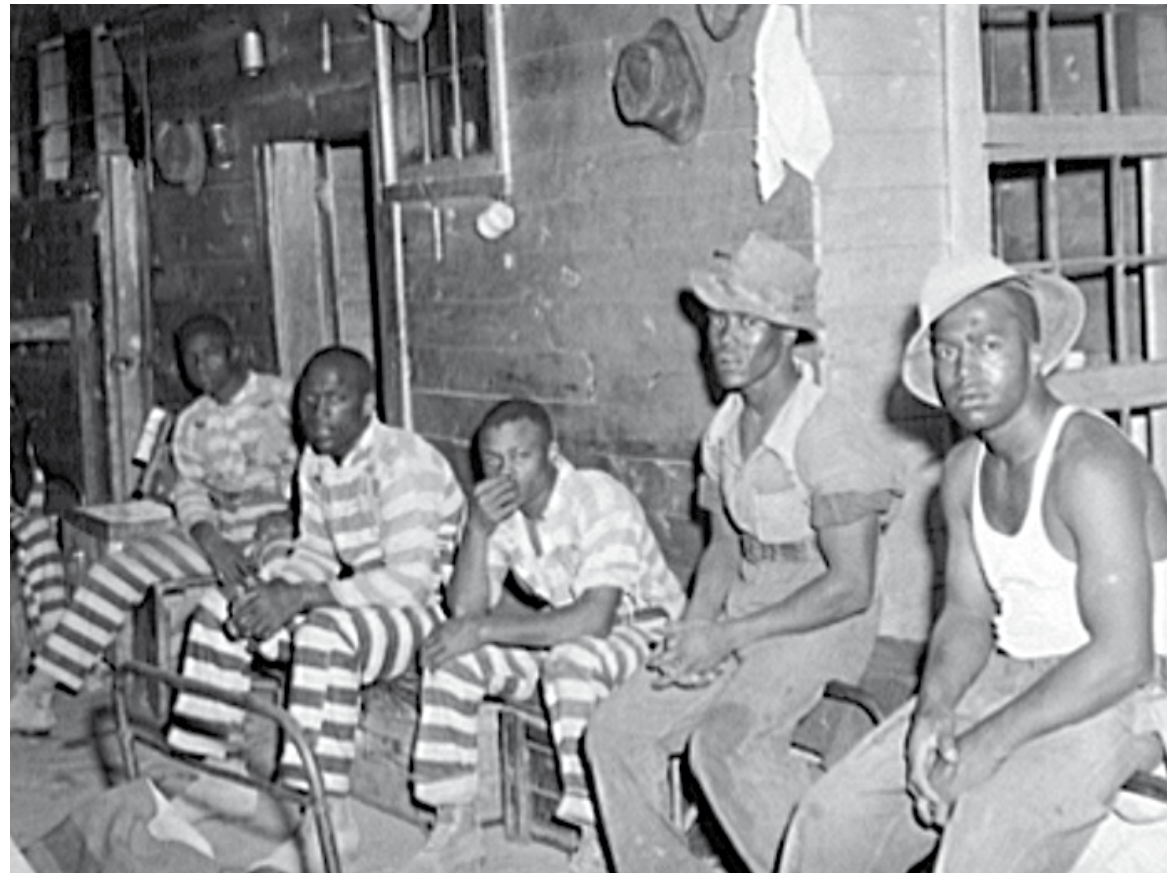

University, Hong Kong; Elena de Hoyos Perez, a sociologist and creative writer who has undertaken field work in Atlacholoaya prison in Morelos, Mexico, and creator of the documentary Under the Shadow of Guamuchil; and Stephan Steiner, a historian from Sigmund Freud Privat Universitat in Vienna. A resulting edited volume in the Routledge series

\section{Explorations in Crime and Criminal} Justice Histories series will be published in 2014.

Through its website and network meetings, the Translating Penal Cultures network has begun to develop an intercultural and international dialogue on incarcerated populations and carceral institutions, and comparative study of their geography, forms of labour, and cultural production. Members are exploring the developing language of penality in a variety of cultures and time periods, and how this connects to the internationalisation and globalisation of penal policy and debate of the past 100 years.

\section{Contact}

Dr Vivien Miller

University of Nottingham

e: Vivien.Miller@nottingham.ac.uk w: www.translatingpenalcultures.org 


\section{Un-Americans and the Un-American}

The idea of 'un-American' behaviour is closely associated in public memory with the McCarthy hearings of the 1950s and the theatrical showmanship of the House un-American Activities Committee (HUAC) during the Cold War. This project, Un-Americans and the Un-American, seeks to widen our understanding of a term that first emerged not in the 1950s but in the Revolutionary period of the eighteenth century, and which continues to be used in some quarters to describe President Barack Obama's perceived alterity. Most importantly, the idea of who was un-American, or what constituted un-American behaviour, has always been deeply contested. Through the rich contours of that long history, changing definitions of un-Americanism have had a direct impact upon key areas of US history, including governance,

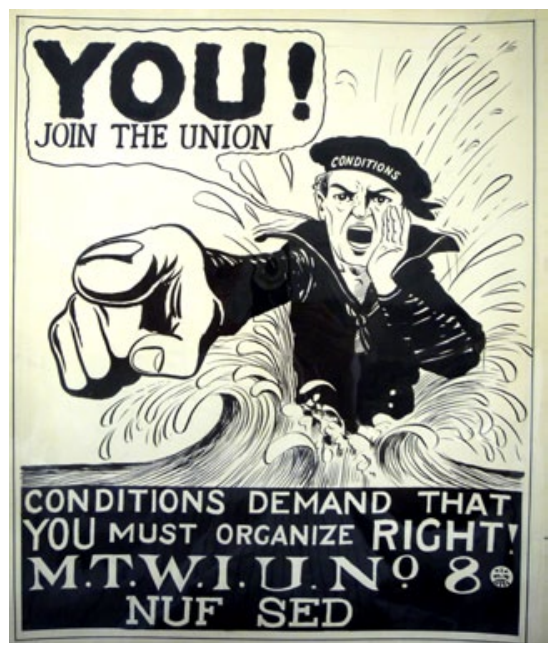

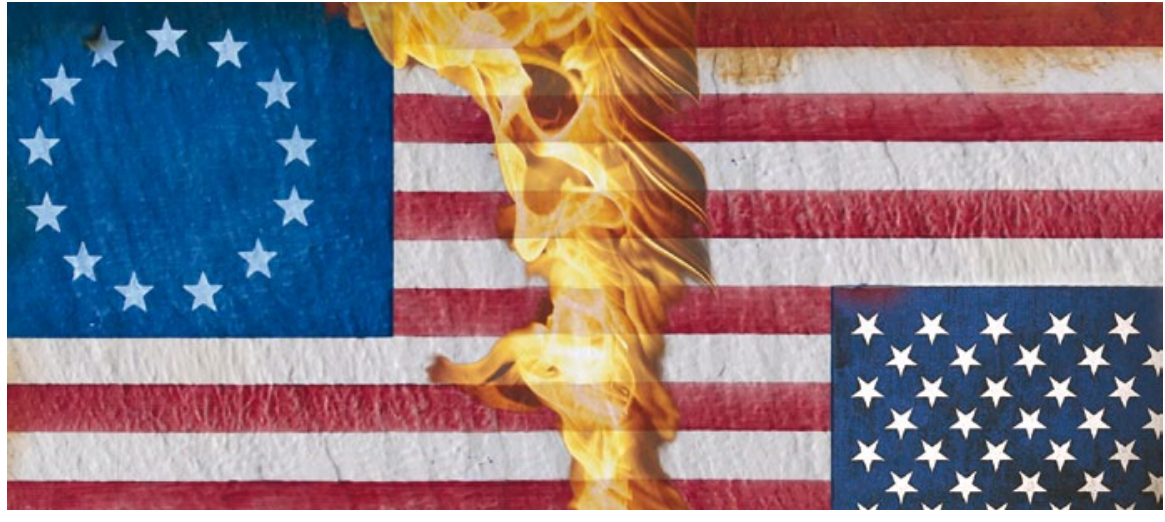

immigration, race and religion, and have also added rich textures to our understanding of what it means and has meant to be American.

As part of a three-year British Academyfunded project, George Lewis (University of Leicester) organised a 3-day international conference (September 2011) that brought together delegates from five different nations to generate the first sustained analysis of the concept of un-Americanism, and the ideas that lie behind the term. The conference showcased the interdisciplinarity that such a project demands, representing fields of cultural, intellectual, social and political history, literature, sociology, law, gender studies, art history, creative writing, and religious studies.

The project's culmination will be a special issue of the Journal of American Studies and a monograph, but it has also produced a column and a blog in The Guardian newspaper, talks for four public lecture series and a panel at the BAAS annual conference. Research for the project has been based on rare books and a rich archival base that has included unprecedented access to the HUAC archives, which were only opened to historians in 2001 and contain 1,245 linear feet of material, much of which centres on the Ku Klux Klan, as well as the archives of 'patriotic' organisations such as the American Legion, investigatory bodies such as New York State's Lusk Committee, religious organisations such as the Mormons, and individuals whose careers were built around contesting the nature of un-Americanism.

\section{Contact}

Dr George Lewis

University of Leicester

e: gdgl1@le.ac.uk 


\section{The American Presidency and Tribal Diplomacy}

This project addresses the most important question in twentieth-century Native American politics: how decisive were personal tribal relationships with individual American presidents? The answer could alter fundamentally not only our existing understandings of the presidency but also how we conceptualize relationships between 'small nations' and dominant powers more generally.

The principal investigator on the American Presidency and Tribal Diplomacy, Joy Porter (University of Hull), was awarded a British Academy Mid-Career Fellowship (2011-12) whilst working at the University of Swansea. This is work of profound interest to Native peoples and to anyone curious about how individual presidential administrations functioned. Research was carried out at the Richard Nixon Presidential Library in California and at the Center for Southwestern Research, University of New Mexico. Joy Porter interviewed a number of Indian leaders and made links with a series of Indian and museum bodies as part of the work. The research will be published as a monograph in conjunction with a podcast, radio slot and public television show produced by American Indian Radio on Satellite and Native American Public Telecommunications, Lincoln, Nebraska.

One particular interview was with LaDonna Harris, Comanche leader and president and founder of

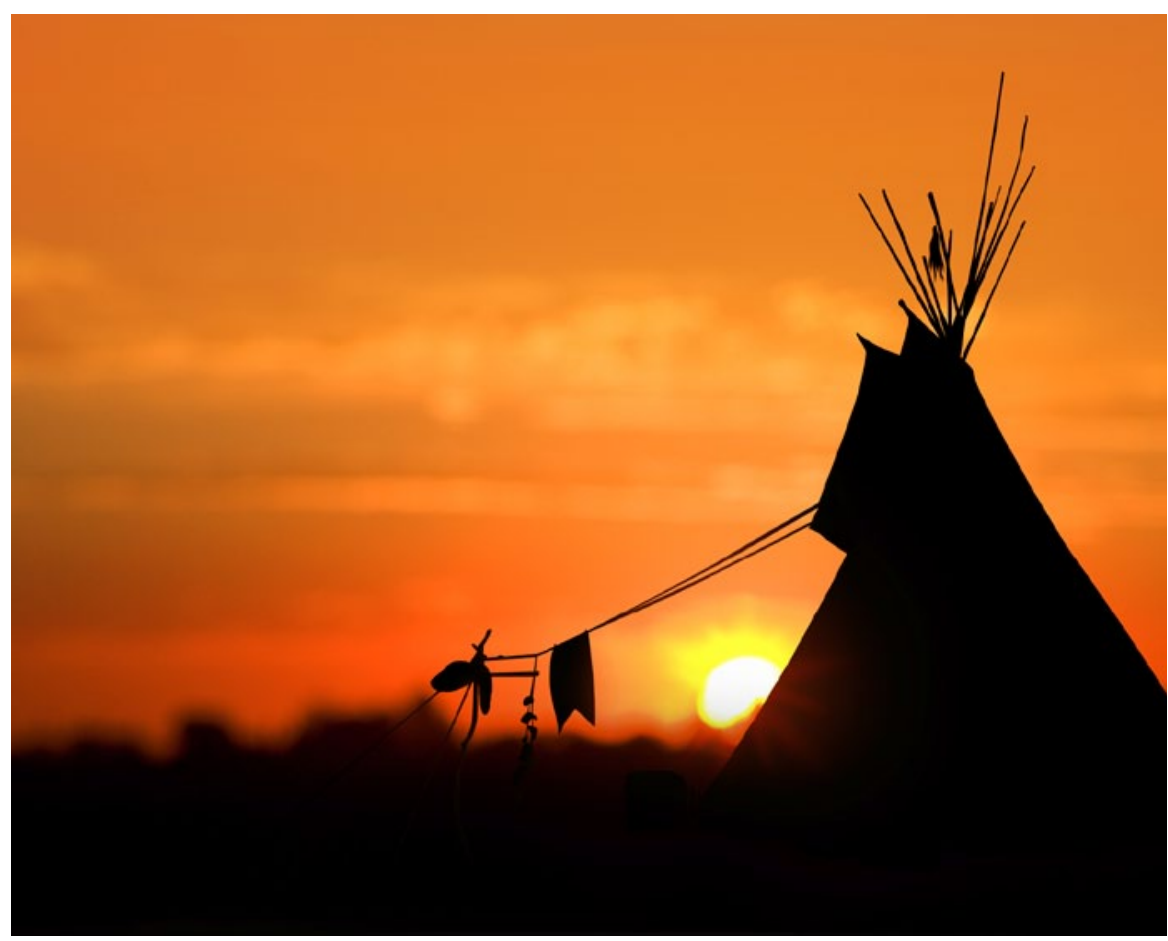

\section{Americans for Indian Opportunity} at her home in Albuquerque, New Mexico, summer 2012. The discussion centred on how LaDonna had recently successfully arranged for the Hollywood actor Johnny Depp (who claims Indian ancestry) to be adopted as an

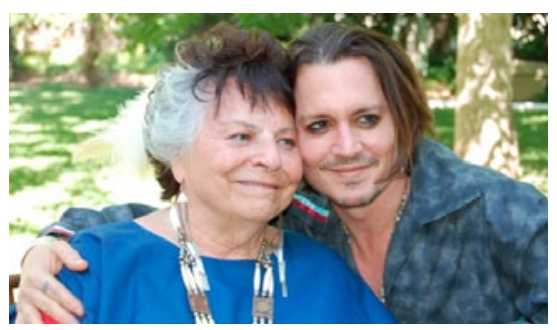

honorary member into the Comanche nation at the same spot a few months previously. Harris was instrumental in achieving the feat of getting the US to return environmentally significant and sacred lands to Indian peoples in the 1970s when the Taos Blue Lake in the mountains of northern New Mexico was given back to the people of the Taos Pueblo.

\section{Contact}

Professor Joy Porter

University of Hull

e: joy.porter@hull.ac.uk 


\section{The English in North America in Transatlantic Perspective}

This project examines the English in the United States and Canada over 200 years, focusing on an immigrant group that has received relatively little exposure to the historian's gaze. Traditional scholarship has, in fact, described them as 'invisible migrants' or sometimes as having 'no ethnicity'.

Locating the Hidden Diaspora: The English in North America in Transatlantic Perspective, 1760-

1950 challenges the established view by studying English migrant cultures in North America from the mid-18th century to the mid-20th century. The project explores the extent to which English associations, such as the St George's Society, were ethnic, and how they might be considered this way. Secondly, it examines how AngloAmerican relations played out for these immigrants. And, thirdly, it traces the diffusion of English culture in North America and the ways in which both Americans and English immigrants perpetuated it.

Funded by a major Arts and Humanities Research Council grant over three years (2012-14), the project is led by three historians at Northumbria University in Newcastle - Don MacRaild, Tanja Bueltmann and David Gleeson - but also includes scholars from literature and folklore studies. At the heart of the project is the exploration, through historical methods, of a series of outstanding associational archives in

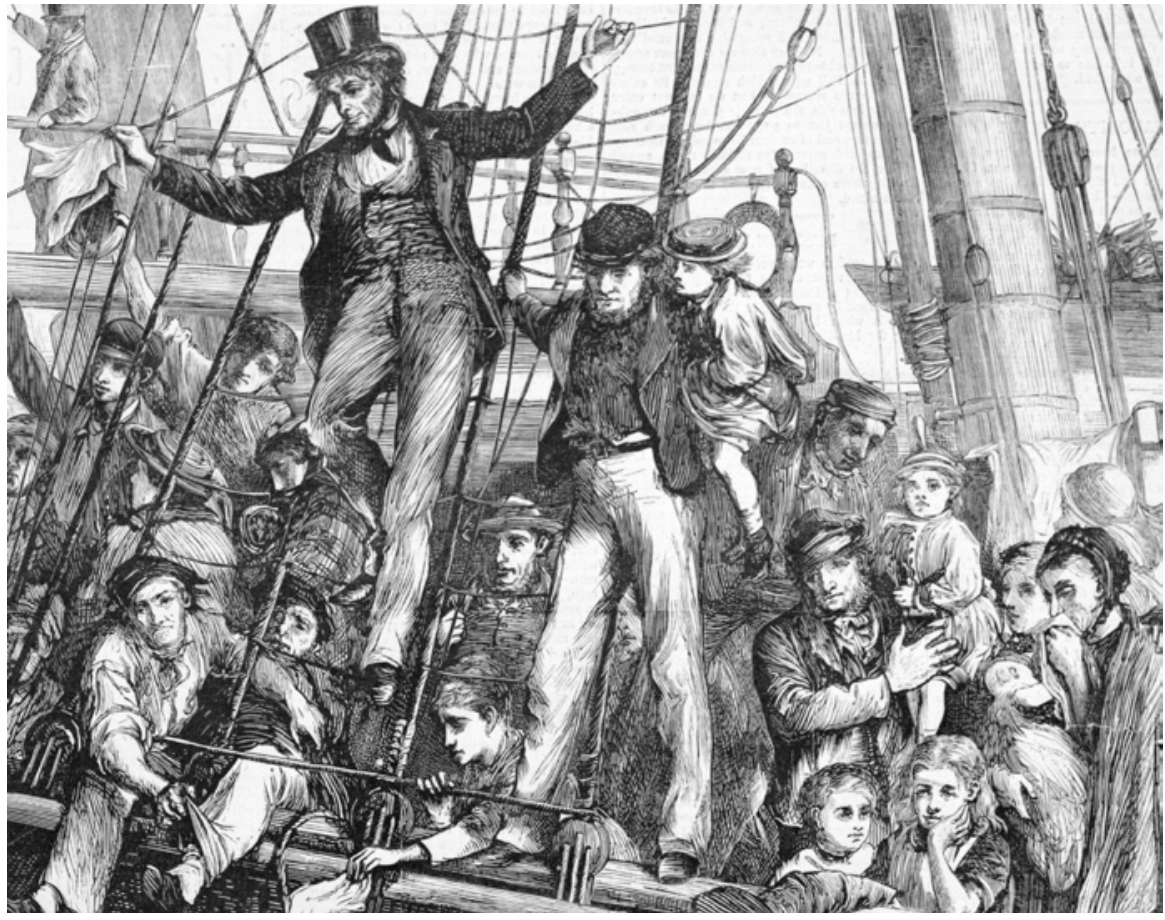

cities from Charleston in the South, through New York, to Ottawa and Toronto in the north.

The project has the potential to make us think again about the invisibility of the English in North America and to look at their relations with other ethnic groups. It challenges notions that, as the original founders of Anglophone culture in the American and Canadian colonies, the English simply disappeared into a host culture that their forebears had forged. Whilst integration was easier for an English immigrant than for a Pole or African, the pathway to assimilation was sometimes pitted with complications and conflicts. By working with non-academic agencies, museums, and English associations, the project team looks to achieve impact beyond the two books, several articles, conference and doctoral thesis which are the core outputs, making extensive use of social media and the press.

\section{Contact}

Professor Don MacRaild Northumbria University

e: don.macraild@northumbria.ac.uk w: www.englishdiaspora.co.uk 


\section{UK-US Relations in an Age of Global War}

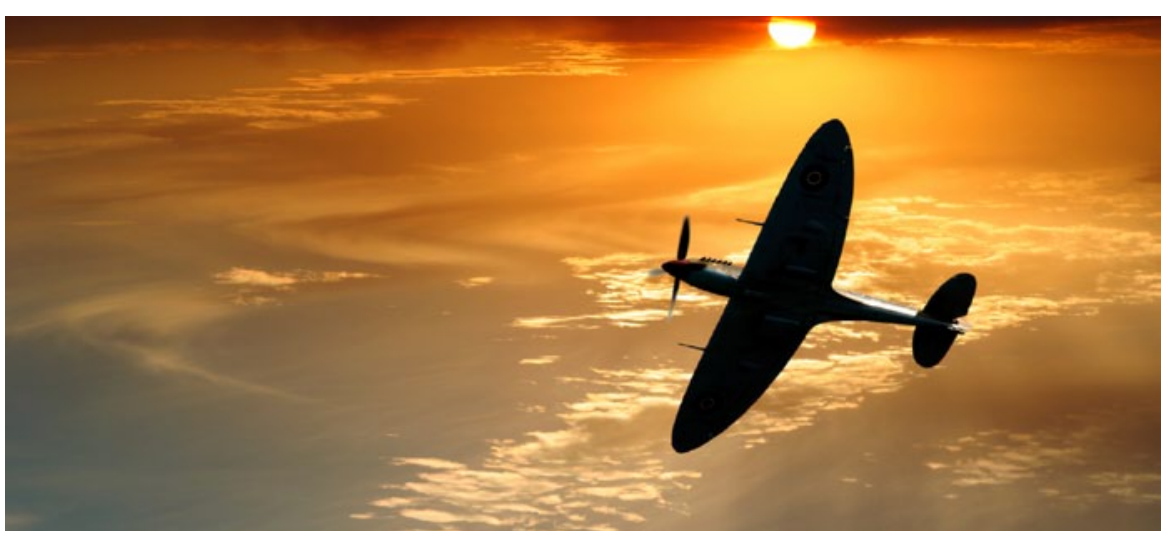

\section{The Atlantic Archive: UK-US}

\section{Relations in an Age of Global War}

1939-1945 project based at the Institute

for the Study of the Americas examines

official British perspectives towards the

United States during World War II on

political, economic and social issues. The

primary aim is to build a comprehensive

online database of digitised British

government documents focusing on

the US during six years of international

conflict, primarily drawn from the

\section{National Archives in London}

(www.nationalarchives.gov.uk). To

support research into the field of

Anglo-American relations an online

hub has been developed from which

researchers can access the database,

suggest documents to be digitised, engage with researchers through

forums, and read the project blog.

The project supports researchers in multiple ways. Firstly, it provides an online one-stop shop for all those due to the database's full-text search capabilities, a researcher can readily access all documents containing keywords, allowing for focused research. Thirdly, it provides researchers with the capacity to find new avenues for research in an already well-explored field: for example, a series of documents discussing UK and US sovereignty disputes over particular Pacific islands during the 1930s and 1940s. Fourthly, the success of the project is dependent on the breadth of the field: to date, approximately $\mathbf{5 0 0 0}$ images and $\mathbf{2 0 0 0}$ documents feed into the online hub. Finally, this resource also enables history and politics teachers to readily access primary documents for classroom teaching.

The Institute for the Study of the Americas, in collaboration with the Centre for International Studies and Diplomacy at the School of Oriental and African Studies will hold an international conference in late 2013 on twentieth-century transatlantic relations, at which the Atlantic Archive database will be launched. The project has been funded through the School of Advanced Study, University of London.

\section{Contact}

Dr Matthew Hill

Institute for the Study of the Americas

e: matthew.hill@sas.ac.uk

w: atlantic-archive.org 


\section{Schools" Project: What America Means to Them}

British children interact with the culture of the USA on an almost daily basis, more often than not, without realising that they are part of a global process of cultural exchange. American television programmes, Hollywood films, popular music, fashion, and food, are integral parts of our children's lives. Whether they are watching The Simpsons, the most recent Hollywood blockbuster, listening to the latest $r \& b$ track, surfing the web, eating fast-food, or asking for Nike trainers, they are engaging with a culture that is both far removed from and entirely intertwined with their own.

The outreach project of the School of American Studies at the University of

\section{East Anglia, What America Means}

to Me, works with local schools to workshop the place of the US in the lives of the children, particularly its history and diverse cultures. America has left an indelible mark on the physical and cultural landscape of East Anglia; indeed, the local area was known as 'little America' due to the presence of American airmen in World War II, and the workshops allow

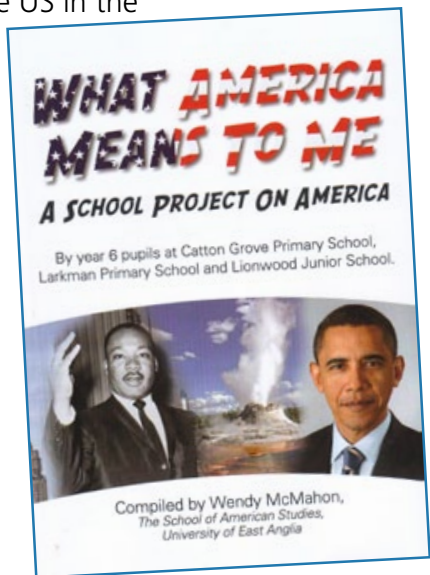

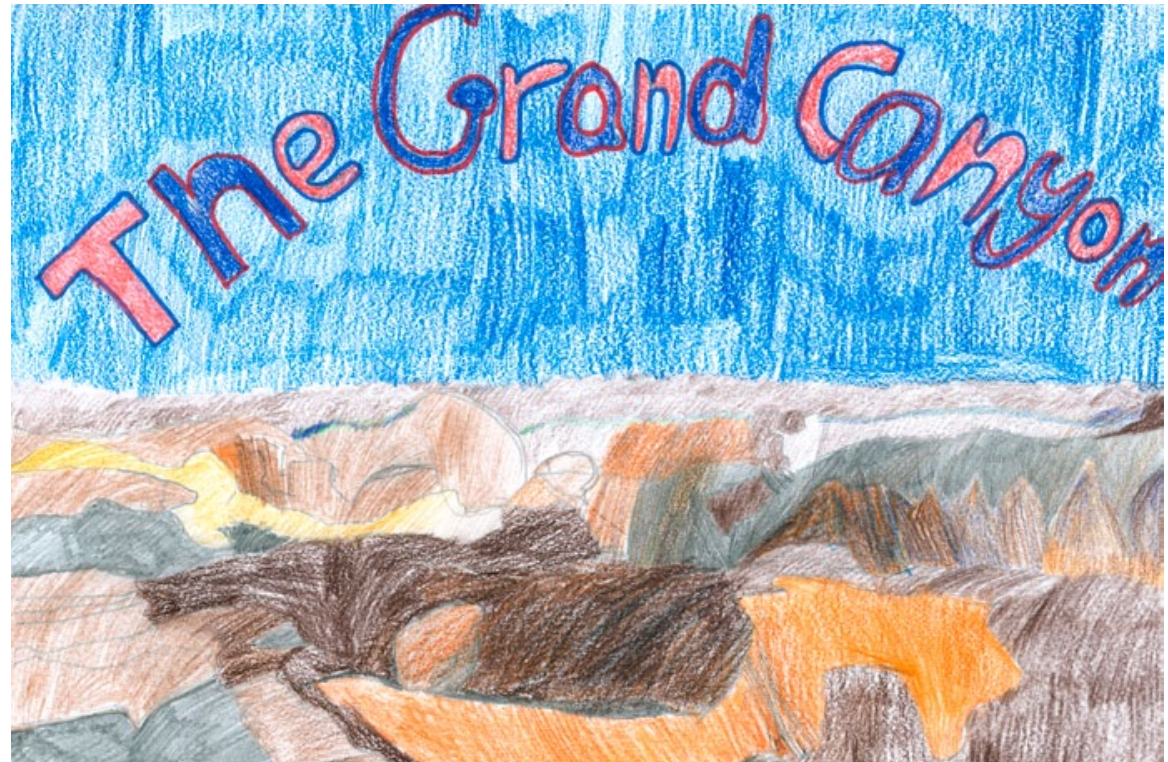

The workshops offer a space for a range of activities: from thinking about how much American popular culture influences perceptions of the place and its peoples, through imagining the group as part of the Lewis and Clarke expedition across the newly acquired lands bought in the Louisiana Purchase of 1803, exploring the roots of today's popular music, contemplating the values upon which the US is founded, and considering the place of America in East Anglia.

The school children produce creative work as a result of their explorations and this has been published in a dedicated book, What America Means to $M e$, as well as an annual exhibition in The Forum in Norwich. The project is becoming part of the cultural life of the local area and has brought the field of American Studies into the view of both children and teachers.

BAAS runs regular conferences for schools, organized by the BAAS Teachers' Representative. In March 2013 we ran two conferences on US Politics and Government in Leeds and Cambridge.

\section{Contact}

Dr Wendy McMahon University of East Anglia

e: Mcmahon@uea.ac.uk w: americaschoolsproject.wordpress.com 


\section{American Studies Doctoral Research}

Doctoral research on North American topics in the UK has grown significantly over the last fifteen years. BAAS continues to support and nurture doctoral research across the range of its subject areas, supported by an annual postgraduate conference, a recent collaborative biennial event for doctoral students and early career scholars with the Irish Association for American Studies, and through the postgraduate online journal U.S. Studies Online (usstudiesonline.com) This page profiles two PhD projects to give a flavour of some of the exciting doctoral work taking place in UK universities.

\section{Writing US Identities in the Persian Gulf and Iraq Wars Jenna Pitchford-Hyde}

This project examines US identities in the narratives that emerged from the Persian Gulf conflict (1990-91) and the Iraq War (2003-9). The thesis constructs an interdisciplinary study of this new field of literature - including novels, memoirs, poetry, graphic novels, and blogs - to explore the effect of

\section{Hair Affair: Media, Culture, and the Business of Black Hair Carina Spaulding}

As an industry which grew from amassing $\$ 332$ million in 1975 to nearly $\$ 3$ billion today, ethnic beauty and hair care has had a shifting, but ever-present face in the United States. Carina Spaulding's thesis investigates topics of identity, assimilation, and representational politics in the black hair care industry in the years following 1975, using an interdisciplinary approach to analyse case studies of contemporary war on identity. These literary responses to the Gulf and Iraq Wars highlight experiences which often sharply contrast with dominant political and media discourses, particularly on issues of identity, communication and technology. The research was supported by Nottingham Trent University (where the thesis was written), BAAS and the US Embassy in London and draws on archival material at the Library of Congress, Washington Navy Yard, the Fort McNair

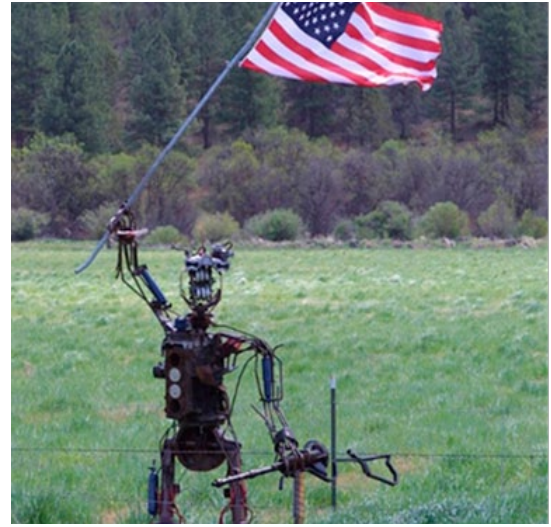

Army base, and the University of Connecticut. The project assesses the impact of contemporary warfare on both combatants and civilians Research from the project will be included in an international open access online project on Future War and an anthology of Gulf War poetry which will open up the topic to the wider public. groups working in the black hair and beauty industry and organising workshops to encourage teens to reflect on the effects of media representations of women on self-image.

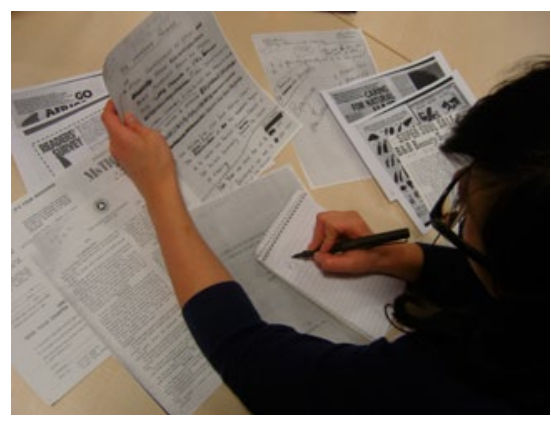




\section{American Studies Resources}

There are a broad range of publicly accessible American Studies resources in the UK, ranging from the American Museum in Britain located in Bath (www.americanmuseum.org) to Sulgrave Manor in Northamptonshire (the home of George Washington's ancestors), from the activities of research centres at the Universities of East Anglia, Glasgow, and Sussex, and the Institute of the Americas at University College London to the availability of specialist library holdings at universities such as Nottingham, Manchester, Leicester, Keele and Birmingham. Here we profile two of the most significant institutions in the UK for promoting American Studies research and for facilitating public engagement.

\section{Eccles Centre for American Studies, British Library}

The Eccles Centre works to increase awareness of the British Library's collections relating to North America and to facilitate the use of the collections. The Centre works in a versatile manner - through academic,

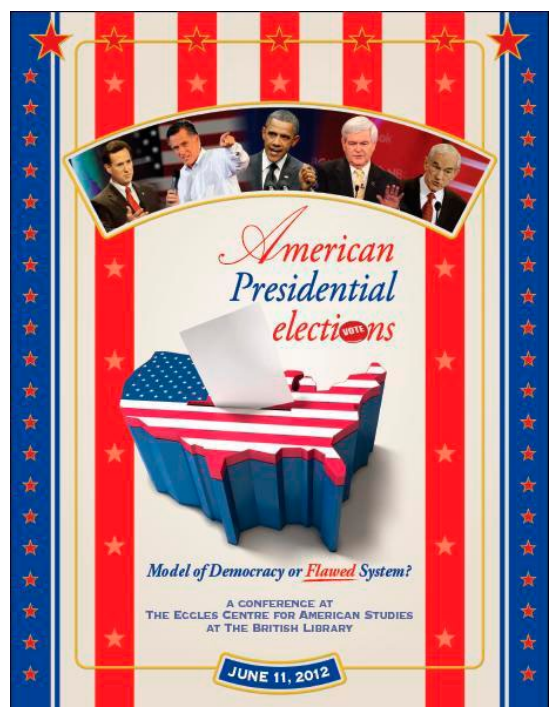

public and schools events, exhibitions, publications, digital outreach, the provision of fellowships, visiting professorships and writer-in-residence awards. Among recent successes the Centre's efforts have facilitated the donation of the Michael Katakis archive of photographic images to the British Library, while Naomi Wood's novel Mrs Hemingway (Picador, 2014) was completed when she was Writer in Residence at the Eccles Centre. Twice annually the Centre's Congress to Campus programme brings former Members of the US Congress to the UK for a week-long series of events with a broad audience including school and university students, researchers, politicians, diplomats, and business leaders.

\section{Contact}

Professor Philip Davies

e: Philip.Davies@bl.uk

w: www.bl.uk/ecclescentre

\section{Rothermere American Institute}

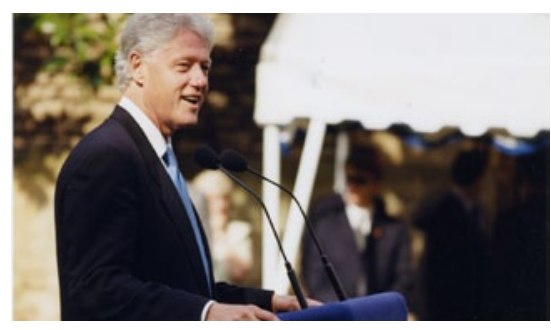

The University of Oxford founded the Rothermere American Institute in 2001 with a clear mission to promote "greater public and academic understanding of the history, culture and politics of the United States". The RAl is sustained by the world-class

Vere Harmsworth Library and, in the ten years since its foundation, the Institute and Library have become hubs of academic research and teaching. Annually the RAl hosts more than 100 seminars, workshops, conferences and lectures that attract international scholars, students, policy-makers and public figures to debate and study the United States. The RAI and Library are open to all academics and members of the public with interests in - as President Bill Clinton put it when he opened the RAI in 2001 - the topics of where America has come from, where it finds itself, and what it is doing in the world.

\section{Contact}

Dr Nigel Bowles

e: nigel.bowles@politics.ox.ac.uk

w: www.rai.ox.ac.uk 


\section{British Association for American Studies}

\section{The British Association for American}

Studies was founded as a scholarly association in 1955. Over the last 60 years BAAS has supported the study of the United States in the universities, colleges and schools of the United Kingdom, and encouraged public engagement with the United States through conferences, special events, publications, awards and outreach activities.

BAAS is among the largest American subject associations in Europe and is a constituent member of the European Association for American Studies (www.eaas.eu), which holds a biennial conference across the representative European nations. As part of a wider global network of American Studies associations, we have strong links to the American Studies Association, the Organization of American Historians, and the International American Studies Association.

\section{In 2012 BAAS commissioned a report in conjunction with the Fulbright} Commission: American Studies in the UK, 2000-2010 (available at the BAAS website, www.baas.ac.uk). The groundbreaking report outlines institutional changes in American Studies across the first ten years of the twenty-first century and traces disciplinary developments, undergraduate recruitment patterns, study abroad opportunities, research centres, and the 2001 and 2008 Research Assessment Exercises that measured research strength in UK universities.

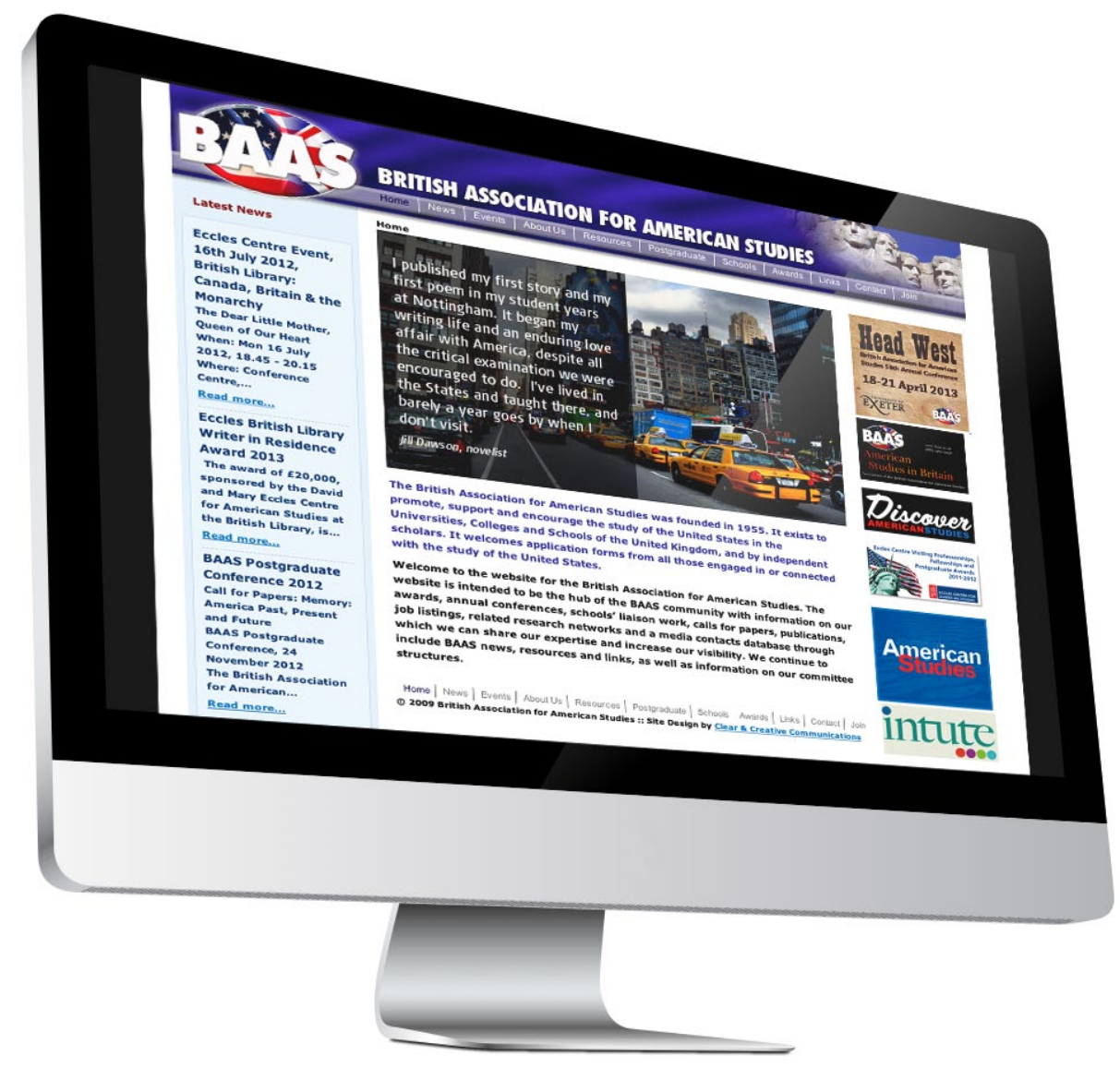

\section{Message from the 18th Chair of BAAS}

We hope you have enjoyed reading about these exciting projects that give an indication of the breadth and importance of American Studies research in the UK. These diverse research projects offer further opportunities for collaboration, new modes of communication, and fresh ways to promote public engagement with one of the most innovative subjects in the humanities and social sciences.

\section{Professor Martin Halliwell}

Chair of BAAS (2010-13) 
Centre for American Studies

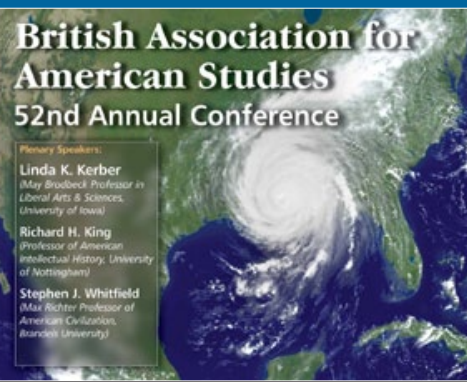

19-22 April 2007

$\triangle$ For further details contact:

BASS

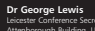
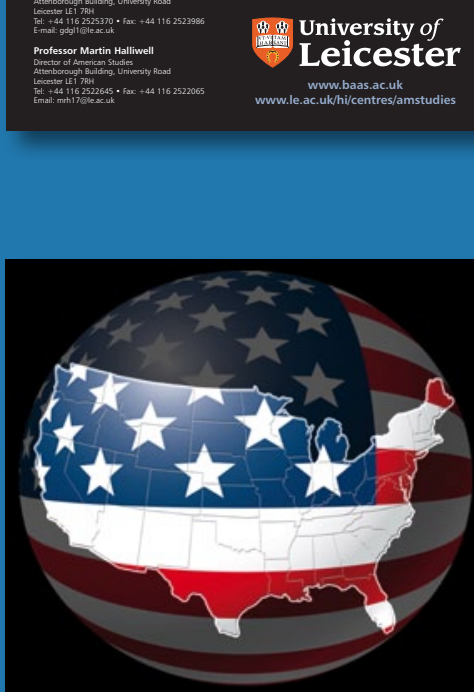

56th Annual Conference

British Association for American Studies UCLan 2011

The University of Central Lancashire

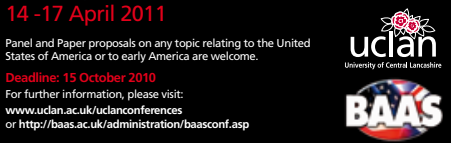

ments
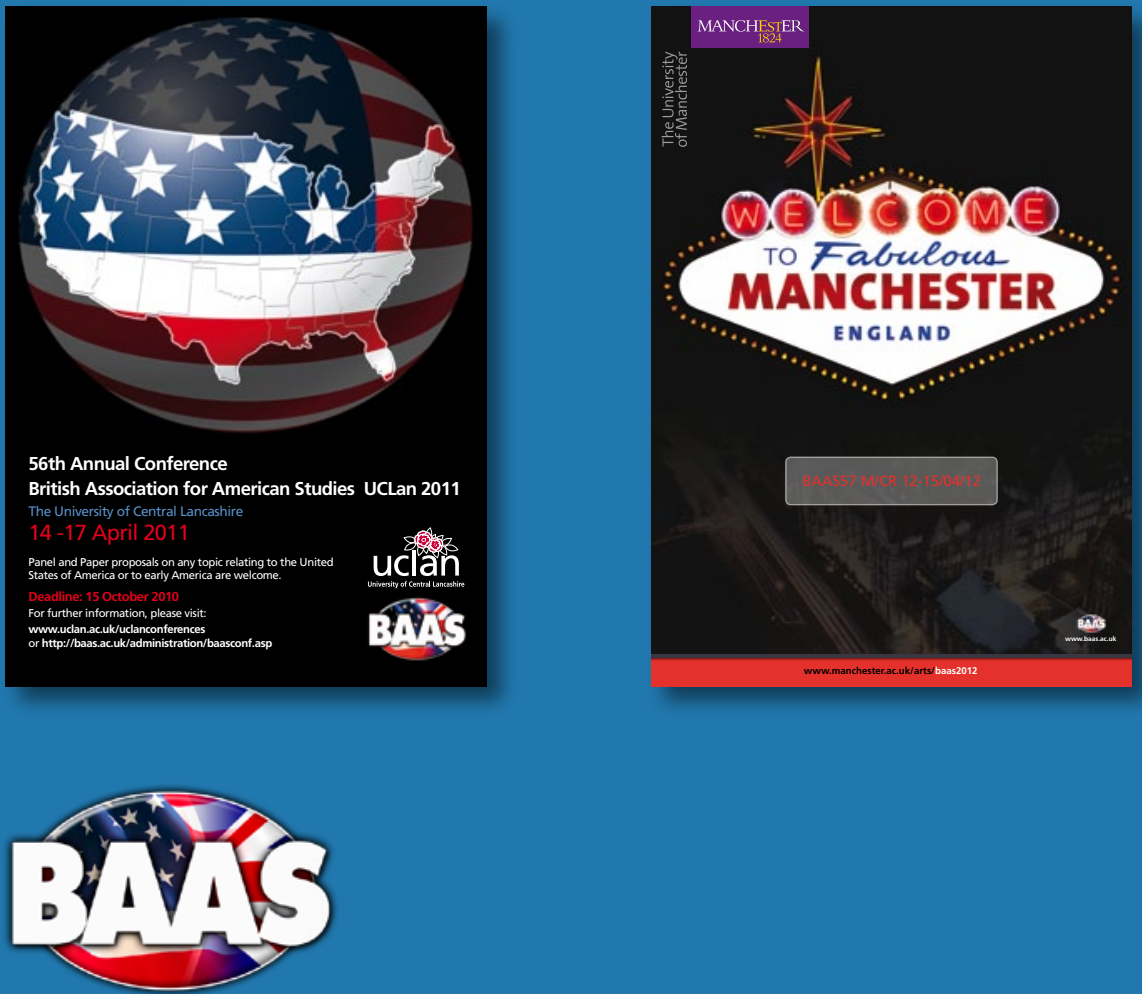

The University of Edinburgh
school of History, Classics and Archaeology

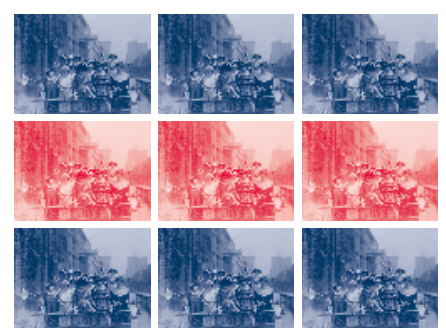

British Association for American Studies $53^{\text {rd }}$ ANNUAL CONFERENCE 27-30 March 2008 Paper and panel proposals on any topic
relating to the United States of America relating to the United States of America
or to early America are welcome.

(BAti. F) For further intormation, please visit alline 15 o
55TH ANNUAL CONFERENCE

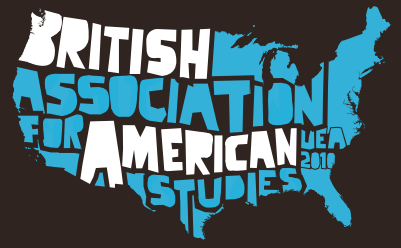

The University of East Anglia School of American Studies 8.11 APRIL 2010 Paper and panel proposals on any topic relating to the
United States of America or to early America are welcome DEADLINE: 16 OCTOBER 2009 Plenary Speakers

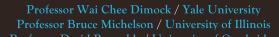
For further information please visit:
wwwwhass.ac.uk/baascenffhrm UEI (BAAS)

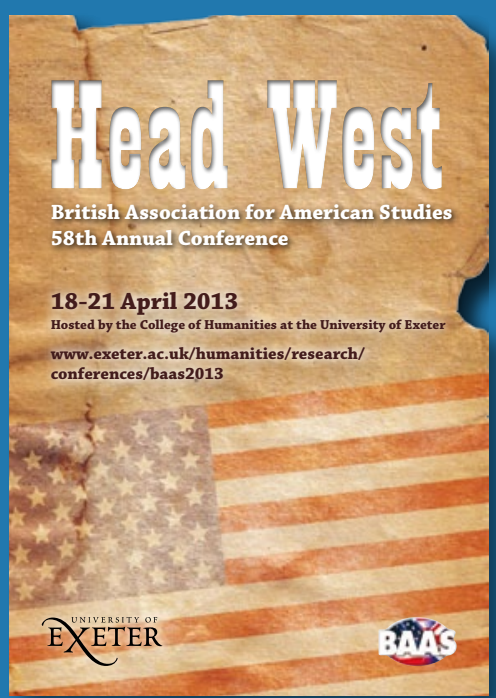

www.baas.ac.uk 